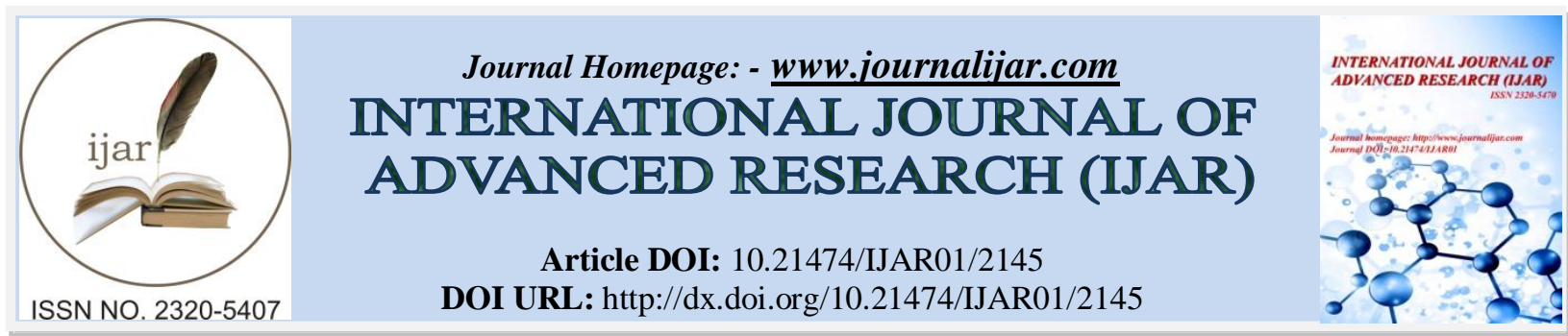

RESEARCH ARTICLE

\title{
HAMLET, HAIDER AND THE MOUSETRAP: THE PERSONAL AND THE POLITICAL IN ELSINORE AND KASHMIR.
}

Abhijith T S.

\section{Manuscript Info}

Abstract

Manuscript History

Received: 25 September 2016

Final Accepted: 27 October 2016

Published: November 2016

Copy Right, IJAR, 2016,. All rights reserved.

\section{Introduction:-}

History plays a pivotal role in shaping an individual. So an individual may act not only on personal grounds, but one can be moved by political motives as well. James Baldwin in his famous essay "Stranger in the Village" states, "people are trapped in history and history is trapped in them"(162). Shakespearean canon has provided a crucial touchstone for the scholarship of adaptation as a literary practice and form. This paper is an attempt to explore the contours of politicisation of the personal when the Shakespearean masterpiece Hamlet is transplanted to the Kashmiri soil as Haider (2014) by Vishal Bhardwaj. This exploration is done by peeling off the inset play named mousetrap from Hamlet and its adaptation in Haider as a song beginning "Bismil Bismil".

In the field of literature Roland Barthes once declared that "any text is an intertext" (39). Ideas presented in a text are not finished and consumable products. They are presented in such a way as to encourage readers to come up with their own interpretation of its meaning. Julia Kristeva, who coined the term intertextuality argues that authors do not create their texts from their own mind, but rather compile them from pre-existent texts. Thus, the text becomes "a permutation of texts, an intertextuality in the space of a given text," in which "several utterances, taken from other texts, intersect and neutralize one another" (Kristeva36). She argues that, the text is not an individual, isolated object but a compilation of cultural textuality. Kristeva believes that the individual text and the cultural text are made from the same textual material and cannot be separated from each other. Texts cannot be separated from social and cultural textuality and all texts contain ideological structures expressed through discourses. Adaptation is category that comes under the over-arching practice of intertextuality.

"Adaptation can be transpositional practice, casting a specific genre into another genric mode, an act of re-vision in itself" (Sanders 18). Additions, expansions, accretions and interpolations can be done to the original text so that the adaptation becomes relevant and comprehensible to new audiences and readerships. Worthy adaptations are significant since they are embellished with the richness of the source text and the profundity of the cultural medium to which they are transmigrated. When a text moves across cultures, its reception is immensely geared by its contextualisation. Hamlet, which can be regarded as one of the monumental pieces of literature ever written, has been adapted across various cultures. It has been made into movies in different languages. Haider, adapted from Hamlet, is part of a trilogy of films based on Shakespeare's plays directed by Vishal Bhardwaj and co-written by Basharat Peer and Bhardwaj. In this adaptation, the personal motive behind King Hamlet's murder is politicised.

This adaptation encompasses various layers. In Hamlet, the inset play is introduced in the second scene of the third act where prince Hamlet tries to catch the conscience of the king through a play. The play is actually "Murder of 
Gonzago" and it is intentionally archaic and artificial in type as it was necessary to convey the illusion of a stageplay presented before the actors in the main stage-play. Hamlet's assertion that the play is titled "The Mousetrap" is a veiled threat of which the King is perfectly aware, especially as 'mouse' is his term of endearment for Gertrude. He advises the players to "suit the action to the word, the word to the action" so that they would not "overstep the modesty of nature" (Shakespeare 165), for the aim of a play is to hold the mirror up to nature. The exact identification of the "dozen or sixteen lines" inserted in "Murder of Gonzago" is impossible and it does not appear that Shakespeare meant the audience to identify them. When Lucianus enters, Hamlet's comment that he is 'nephew to the King' is intended as another threat, and Claudius suspects that Lucianus' lines are written by Hamlet himself. Claudius watches for the second time the re-enactment of his crime and is about to reveal himself, and when Hamlet gives a last twist to the knife by explaining, "You shall see anon how the murderer gets the love of Gonzago's wife" (176). The King raises terror with false fire. "Murder of Gonzago" can be seen as an old-fashioned on account of its conventionality, its monotonous rhymes, and its rather turgid rhetoric. "Murder of Gonzago" puts both Claudius and the Ghost on trial, the former for 'fratricide' and the latter for its 'honesty'. Hamlet hesitates to act even though his dilemmas are removed to some extent. Hence this play emphasizes Hamlet's delaying nature and it pricks the guilty consciousness of Getrude and Claudius. So it is clear that the intension behind the murder is personal; to marry Getrude. Within this framework, adaptation surpasses various levels. The original play "Murder of Gonzago" is adapted to suit Hamlet's intension and it is inserted to the play. The play Mousetrap takes place at another layer distant to its original form and it showcases the personal intricacies intertwined with the murder of king Hamlet. Claudius wants to have Getrude as his wife and to become the King of Denmark. This motive of villainy is exposed through Mousetrap and the integrity of the character of Claudius is thereby called into question. We cannot completely disregard the political favours behind the murder as Claudius has an eye at the throne too. But it is a part of the power structure and the motive behind the murder can still be asserted as something strictly personal.

On the other hand, Haider presents a different spectrum of attempt made by the protagonist to catch the conscience of his uncle, Khurram. What makes the adaptation different and poignant, is its background of insurgency-hit Kashmir conflicts of 1995 and civilian disappearances. Hilaal Meer, the character equivalent of King Hamlet is accused of harbouring terrorists and is taken away for questioning. He is disappeared from the scenario and Haider who returns from Aligarh Muslim University is shocked to find his mother singing and laughing along with her brother-in-law, Khurram. Being unable to account for his mother's behaviour, he begins searching for his father. 'Shall we be or not be?' was the line that we can see in the banner held by Haider outside the gates of the UN office where the parents and relatives of the disappeared civilians assembled. The question of existential problem revolving around Haider can be squeezed out of this very scene itself. From a stranger named Roohdaar, he comes to the realisation that his uncle Khurram is behind his father's fate and Roohdaar asks Haider that his father has demanded to avenge his betrayal by his serpent of a brother.Hilaal wanted Haider to aim bullets the cunning and deceiving eyes of Khurram who entrapped Haider's mother Ghazala and made him an orphan. This is what that leads Haider to stage a performance where he can expose the vicious nature of his uncle. It would also be an opportunity to prick his wicked conscience and thereby disturbing his mental landscape. The question whether his mother has any role in the murder is still under doubt, but Haider is pretty sure that his mother will not intentionally stand with his uncle to murder her husband. The portion corresponding to the inset play in Hamlet appears in the movie after the religious ceremony of engagement between Ghazala and Khurram.

The Hamletian Mousetrap is brilliantly adapted to the Kashmiri setting as a song which is pregnant with the undercurrents behind the death of Hilaal Meer. The setting is like an amphitheatre where a group of friends and dignitaries have gathered and the mood is that of a festival. The guests congratulate Ghazala and Khurram who are seated on throne-like chairs. The Bhaand Pather begins and masked entertainers come twirling in with the sounds of live instruments. A masked Haider takes the narrator's role and there are players performing the role of old king, the new king and the queen along with their subjects. However, this is more like code words, so they would not understand in the beginning, and it would settle in slowly as the story proceeds. The song starting with "Bismil bismil bulbul-e-bismil" tells the story of the newly-crowned king after he betrayed and murdered his own brother, the older king. The lyrics of the song are deeply symbolic as it is narrated as the story of a nightingale (bulbul).

The nightingale stands as a symbol of Ghazala where Khurram is symbolised as the wicked falcon. The singer asks the nightingale of the hurt one not to meet the flower. He narrates the story of a pair of male-female in which the nightingale was straightforward and the male was simple too. There was a falcon with very bad intentions. It used to fly in the sight of greeneries and death was hidden in its wings, party after party, it was looking for a destination of 
castles. It had gone to the dreams of the nightingale, spread gunpowder in the valley, and spread nets in the lake. With knives, it got both the wings of the poor male cut got him tied with chains. Then he threw the heart of the male in water from Shirinpur of Baramulla. The water in the Jhelum River became red. The effect of Kashmir's water, chains and fates got dissolved. The singer alarms that he is alive. He adds that he would be alive and the culprit will be embarrassed. Then the singer concludes the song by asking the nightingale to come to her conscience and never to ward off his story as a lie. The song clearly exposes the brutal hands behind the murder. In contrast to Hamlet, this song brings to light the political underpinnings behind the betrayal and murder. The song exposes the situation where the old king gets disliked by the feudal lord who conquered their kingdom. His brother was hand-in-glove with the feudal lord; therefore they both conspired to trap the old king and killed him to ensure that the kingdom and the queen would be the new king's forever. Even the details of the killing with the body being thrown from the 'Zero Bridge' are exposed through the song. Haider ends his performance by kneeling before Khurram. Khurram and Ghazala were quite disturbed.

Bhardwaj superimposed his enduring experience derived from reading Basharat Peer's gut-wrenching account of the biggest tragedy of modern Indian history, the story of Kashmir as depicted in Curfewed Night and the greatest tragedy of world literature Hamlet. Bhardwaj's lines in the "Bismil bismil" song are simmering with political overtones as the movie is set at the backdrop of the insurgency period in Kashmir. Bhardwaj's master-craft in knitting the vicious thread of political disturbance and betrayal on the unsettling wool of Hilaal's murder is remarkable. Thus the personal motive behind the murder in Hamlet is re-casted into a political cause under the Kashmiri backdrop. It is the mid-1990's which the peak period of insurgency in Kashmir is. The Indian defence establishment finds it difficult to penetrate the extremist groups which are supported by Pakistan and protected by the locals. To meet this challenge, the Indian intelligence formed 'Ikhwaan-ul-Muslameen', a counter-insurgent militia comprising of surrendered and captured militants. They were Kashmiris and they knew the militants who were the sympathizers. Khurram was an informer of the Indian Army. Khurram handled most of the cases of the militants caught or surrendered in Kashmir. He worked with the Indian intelligence to form a militia that would kill their own people. Actually Ghazala is also a part of the betrayal unknowingly as it was Ghazala who told Khurram about the wounded militants treated by Hilaal Meer without knowing that he was an informer of the Indian army. Khurram tells Ghazala that he tries his best to save his brother but he was cheated by a man named Roohdaar. Later a stranger named Roohdaar reveals the things encountered by Hilaal to his son Haider. Both Hilaal and Roohdaar were tortured at the imprisoned place and they were taken by the security officers to the 'Zero-Bridge' for execution. They were handed over to the Ikhwaan. While they were pushed forward to walk, a flash of light fell onto the passenger seat of a jeep for a brief moment which exposed the face of Khurram watching them coldly. An Ikhwaani fires on Hilaal followed by firing on the chest of Roohdaar. Their bodies were tied and were thrown from the corner of the Bridge. The rope that tied them got loosened and miraculously the water of Jhelum ceased the bleeding of Roohdaar. Roohdaar was saved by some sand mining villagers and Hilaal's body was found later. Hilaal's body was buried in a graveyard at Boniyar village, a little ahead of Baramulla. This story of betrayal and brutality is thrown symbolically to the limelight by the performance and Haider and others during the song. The song and the performance unveil the political reason behind Khurram's move. Haider, at a point tells his mother about what happened and it is only then Ghazala realises her part in the betrayal. The lyrics of the song are studded with the hue and odour of Kashmiri politics during the insurgency period. The image of the red water of the Jhelum River that carries the blood of some innocent Kashmiris who stood against the stringent and uncouth policies and tactics of the Indian Army is a heart moving piece. The political terror inflicted upon those who stood against the strict and cruel politics of Indian Army in Kashmir is uncovered. The Armed Forces Special Powers Act entrusts prime authority to the army to rule on the people. Anyone who supports the militants or anyone who holds militant views is caught and persecuted even without proper investigation. Indian-controlled Kashmir exploited the Armed Forces Special Powers Act that enables them to "hold prisoners without trial". The group argues that the law, which allows security forces to detain individuals for up to two years without presenting the charges, violates prisoners' human rights. This political issue is called into question in the song. The presentation of the performance is also noteworthy because of the settings and depiction of the betrayal using dummies. The lines of the song are so captivating and thoughtprovoking as it presents in the issue in a symbolic as well as satirical manner.

The political motive behind the murder is clear from the song. Khurram cheats his brother to support the Indian Army and the Ikhwaanis. The civilian disappearance was a usual story during the insurgency period. The AFSPA rules were so rigid as it voids out the personal interests and basic human rights of the individuals inhabiting Kashmir. Hilaal Meer was actually doing his duty as a doctor as he treated and gives resting place to the members of a separatist group. Khurram showed his loyalty to the army by betraying his brother and thereby got the chance of 
marrying his brother's wife to whom he had special concern. The word "chutzpah" which is homonymous or ironically synonymous with AFSPA is used at many instances in this film to expose the political gravity of the situation ironically. The word means audacity or insolence which is very much suited for the entire scenario. The word also designates condemnation, outrage and a sense of disapproval. "Chutzpah" amounts to a total denial of personal responsibility that renders others speechless and incredulous. One cannot quite believe that another person totally lacks common human traits like remorse, regret, guilt, sympathy and insight. The implication is at least some degree of psychopathy in the subject, as well as the awestruck amazement of the observer at the display. In the movie Haider, we can clearly identify the word as a marker of India's way of treating the people of Kashmir since the beginning of the conflicts. Therefore the movie as well as the song clearly suggests that it is not only the "chutzpah" of Haider, it is the chutzpah associated with every individual who has been a part of the insurgency in Kashmir. The tragedy endangering the people of Kashmir is tactically squeezed into a microcosm in Haider. The "chutzpah" afflicted on every Kashmiri is brought to the limelight through the adaptation. The "Bismil Bismil" song acts as a mouthpiece of the political intricacies behind the civilian disappearances in Kashmir and the chutzpah behind every death points finger at the shattered psyche of every individual living in the terror stricken Kashmir.

By drawing parallels between Mousetrap and its adaptation in Haider, we can see that the personal motive behind the murder of king Hamlet is politicised in Haider. It is because of the shift in the cultural framework brought about by adaptation. If we consider the inset play alone, we can see the multilayers of adaptation. There is an Italian play called "Murder of Gonzago". It is modified to suit the intensions of the inset play and is staged in Hamlet. The second layer is the enactment of the inset play and it happens within the framework of Hamlet. When it is adapted to an Indian movie, it again gets transplanted in a different cultural scenario. At that level of adaptation, the central theme of the inset play gets politicised. The vigour and tenacity of the inset play is well kept in its adaptation by a song with its powerful lyrics that unlocks the mystery in a symbolic manner. The intertextual interpolations are almost evident and it underlines the fact that texts have no unity or unified meaning of their own; they are thoroughly connected to on-going cultural and social processes. The meaning of a text is inside and outside the text. Ideas and things are relocated and translated in adaptation that can stimulate new utterances and creativity. As Bhabha suggests, "only hybridity that respects differences enables innovation" (208). Bhardwaj's transplantation of Mousetrap into the Kashmiri setting is indeed one with differences that suit to the cultural realm. The adaptation of Mousetrap in Haider proves that the personal intricacies that stands as a cause in Elsinore gets reshaped as political underpinnings in Kashmir and this itself is the soul of the plot. Thus, through this exploration, we can understand the potentiality possessed by an adaptation to subvert and re-cast meanings and frameworks even when the same thread is adapted to two different cultures.

\section{References:-}

1. Baldwin, James. "Stranger in the Village". Notes of a Native Son. Boston: Beacon Press, 1984. Print.

2. Barthes, Roland. "Theory of the Text". Untying the Text: A Post-structuralist Reader. Ed. R. Young. London: Routledge, 1981. Print.

3. Haider. Dir. Vishal Bhardwaj. Perf. ShahidKapoor, Tabu, Shraddha Kapoor and Kay Kay Menon. 2014. Film.

4. Kristeva, Julia. "The Bounded Text". Desire in Language: A Semiotic Approach to Literature and Art. Trans. Thomas Gora, Alice Jardine and Leon S. Roudiez (ed), Oxford: Basil Blackwell, 1980. Print.

5. Sanders, Julie. Adaptation and Appropriation. London: Routledge, 2006. Print.

6. Shakespeare, William. Hamlet: Prince of Denmark. Ed. Philip Edwards. Cambridge: Cambridge UP, 1985. Print. 